\title{
Developing Interactive Multimedia on the Thematic-Integrative Learning for Grade IV Students under the Sub-Theme my Food is Health and Nutritious
}

\author{
Tri Yuliansyah Bintaro \\ Universitas Muhammadiyah Purwokerto. Jl. Raya Dukuh Waluh, Purwokerto 53182, Indonesia \\ Email: bintaro.pwt@gmail.com \\ Received: 25 November 2015; Revised: 10 April 2017; Accepted: 31 July 2017
}

\begin{abstract}
This study aimed at generative a proper and effective Adobe Flash Interactive Multimedia for Grade IB Students under the sub-theme "My Food is Healthy and Nutritious" in SD Negeri Glagah Yogyakarta. This research and development study referred to the stages that had been developed by Borg \& Gall. The development design was put into four stages, namely: (a) exploration; (b) product development; (c) product testing and revision; and (d) implementation. The subjects of preliminary field testing consisted of 15 Grade IV students in SD Negeri Glagah. Then, the subjects of expanded field experiment consisted of 30 Grade IV students in the experimental group and 29 Grade IV students in the control group; all of these students came from SD Negeri Glagah. The data were gathered using the interview guideline, the interactive multimedia product evaluation sheet, and the test items. The data that had been gathered were analyzed using the independent sample t-test with rate of significance 0.05 . The results of this study have generated the interactive multimedia that according to the material experts and the media experts belong to the "Very Good" category. However, there have been differences in the pre-test results and the post-test results between the experimental group and the control group after both groups were exposed to the interactive multimedia with $p<0.05$. These differences imply effectiveness improvement with $\mathrm{p}=0.005$.
\end{abstract}

Keywords: interactive multimedia, integrative thematic

How to Cite: Bintaro, T. (2017). Developing interactive multimedia on the thematic-integrative learning for Grade IV students under the sub-theme my food is health and nutritious. Jurnal Prima Edukasia, 5(2), $193-202$. doi:http://dx.doi.org/10.21831/jpe.v5i2.7223

Permalink/DOI: http://dx.doi.org/10.21831/jpe.v5i2.7223

\section{Introduction}

Education has been one of the decisive factors for the future generation and has become one of the benchmarks for the national human resources. Therefore, educational needs should always be met and be increased. Basically, the educational system in Indonesia consists of several degrees namely elementary school, junior high school, senior high school, and college or university. These degrees are in accordance to the formulation contained in the Law Number 20 Year 2003 regarding National Education System, which mentions that:

Elementary Education is an educational degree that underlies the high school degree. Elemetary education takes the form of elementary school, madrasah ibtidaiyah, or equally alike and of junior high school, madrasah tsanawiyah, or equally alike.

In relation to the above statements, elementary education as the most fundamental degree should prepare students to enter the high education. Elementary education is demanded to prepare students to be personality with prominence in terms of attitudes, knowledge, and skills. Therefore, the learning process in the elementary school should be able to provide students with certain life skills in order to be the modeled citizens of Indonesia.

Due to this reason, the learning process that has been derived from the curriculum always undergoes changes; not to mention, the curriculum itself also undergoes changes over the time. Prior to the implementation of 2013 Curriculum, there was Educational Unit Level Curriculum (KTSP, Kurikulum Tingkat Satuan 
Pendidikan). Since 2013 Curriculum has just bee implemented, the product testing of 2013 Curriculum may only be started in 2013/2014 Academic Year toward Grade I and Grade IV students. 2013 Curriculum is indeed a curriculum which learning materials are integrated from several subjects such as Natural Science, Social Science, Mathematics, Bahasa Indonsia, and Citizen Education; these learning materials are integrated under certain themes. The learning approach that will be implemented in 2013 Curriculum is the integrative thematic approach. Thematic integrative approach is a learning approach that integrates multiple competencies and subjects into multiple themes. This integration is conducted in two aspects. The first aspect is the integration of attitude and the second aspect is the integration of meaningfully related concept.

Thematic learning emphasizes the implementation of learning by doing concept and the students' active involvement in the learning process. As a result, the students might attain direct experience and are trained to find the knowledge that they should learn on their own. Through the direct experience, students will understand the concepts that they learn and they may associated these concepts to other concepts that they have understood. Such association is in line with the theory of learning psychology that has been proposed by the proponents of Gestalt psychology, including Piaget who stated that learning should be meaningful and be oriented to the children's needs and development. Therefore, thematic learning is appropriate to this theory, which provides meaningful learning process with orientation toward the children's needs and development.

In conducting the thematic learning, teachers should design the learning experience that will influence the students' learning meaningfulness. The learning experience that displays the association of conceptual elements will turn the learning process to be more effective. The conceptual association among the subjects that they learn will form a scheme so that the students will attain holistic knowledge. In addition, by implementing the thematic learning process in Elementary School the students will be assisted because this thematic learning process goes in accordance to their development. Thematic approach essentially is one of the learning approaches that enable students to find, probe into, and find the concepts and the principles actively, holistically, and authentically both as individuals and as group members.

From the phenomena that have been found in the field, there are several elementary schools that have not implemented the 2013 Curriculum comprehensively. There are several obstacles that lie behind this situation and these obstacles have been complained by the teachers in these schools in relation to the support of 2013 Curriculum implementation: (1) both the teachers and the schools still have to adjust themselves to the implementation of 2013 Curriculum, especially in terms of learning time since the schedule of the present curriculum is tighter than the previous one; (2) the more demanding period has caused the teachers to suffer from the difficulties in designing and implementing their lesson plans; (3) the distribution of teacher support book and student book has not been on time; (4) the teachers also have difficulties in handling the abundant and complicated paper-works; (5) the design of students' final assessment becomes procrastinated because they are busy with the abundant and complicated classroom paper-works; (6) along with the development of the age, the teachers have difficulties in meeting the needs of appropriate Information and Communication Technology-based learning media; (7) the multimedia learning materials in the form of Adobe Flash animation for the sub-themes of My Food is Healthy and Nutritious have not been available; and (8) the teachers need to use the multimedia learning materials in the form of Adobe Flash animation for the sub-themes of My Food is Healthy and Nutritious.

Media becomes important due to their multiple benefits. Media may be benefitted by teachers and media also consist of many categories, including pictures, videos, magazines, newspapers, television units, and many more. The use of one or more media is known as multimedia. Multimedia is able to assist meeting the students' needs in attaining the learning information. According to Gayeski in Munir (2012, p. 2), multimedia is a group of computer- and communication system-based media that have the role to build, store, deliver, and retrieve information in the form of text, graphic, audio, video, and alike.

Multimedia cannot be separated from the overall teaching-learning system. The use of multimedia has a positive impact by providing meaningful learning process. Students will 
Jurnal Prima Edukasia, 5 (2), July 2017 - 195

Tri Yuliansyah Bintaro

contemplate the overall learning process more with the presence of multimedia in their learning process. The selection of multimedia components in the teaching-learning system is based on the assumption that the knowledge that the students attain comes from the organized experience, starting from the direct experience that enables the attainment of more concrete knowledge to the experience that might be attained by means of language. As the implication, the birth of technology is expected to be able to improve the learning quality. This is in accordance to the opinion by Fanny \& Suardiman (2013, p. 2) that the beauty, the attraction, and the interactivity in the learning media in a medium is to avoid the students' boredom in attending the learning process and the greatest impact that can be expected is that the students might be motivated and be assisted in retrieving the learning materials. In addition, such learning process can be conducted in the school or in the house.

The presence of computer as part of technological development, with its multiple programs and applications, has provided multiple benefits. The presence of computer is also helpful in attaining information in the form of knowledge, technology, and learning programs; as a result, the computer helps generating a learning model. In other words, the computer serves as an assistance tool in designing a learning model.

With the computer-based learning process, it is expected that the slow learns might keep up with the pace effectively in their learning process since the computer may re-play the necessary information for them. On the other hand, with the use of computer the fast learner may pace up their learning activities (Warsita, 2008, p. 138).

One of the programs that can pack multiple media into the learning multimedia is Adobe Flash. Adobe Flash is the software that has the capacities of drawing and animating; this software is very easy to learn. Adobe Flash is not only operated in the design of an animation but also in other needs such as the design of game, the design of web, the design of learning process, and even the design of movies.

Along with the more advanced science and technology, teachers are more encouraged to operate the tools and the media that have been available in the school. In the same time, they are even more encouraged to create their own learning media. Therefore, the teachers are demanded to have knowledge and understanding about learning media.

The term "media" came from Latin and is the plural form of "medium," which means "mediator or courier" (Djamarah \& Zain, 2010, p. 120). Then, Sidhu (2008, p.455) stated that media is a a Latin word used to describe ways to convey information. Media can be related to newspapers, magazines, radio, television, audiovideo programs, computer, and others. Thereby, media might be defined by a mediating tool or a message courier.

The development in the multimedia technology has promised an enormous potential in transforming how an individual learn and deal with the difficulties in learning mathematics. The Minister of National Education Law Number 22 Year 2006 regarding the Standard of Content mentions that curriculum is implemented using multi-strategy and multimedia approach, using sufficient learning sources and technology, and benefitting the surrounding environment as the learning sources. This statement implies that the utilization of multimedia in the learning process is very helpful for the educators in developing their learning techniques so that the educators are able to generate optimal students' learning results. Similarly, through the multimedia that have been designed the students are expected to have fun and to be motivated in attending the learning process.

The use of multimedia in the learning process might combine the elements of innovation, creativity, and entertainment; this will cause the students to have the sense of fun and to not be bored with the learning materials that the teachers provide. In the same time the teachers are also assisted in preparing their learning materials. If the multimedia are available, the students then might focus their perception, reflection, reasoning, and problem solving. With the development of multimedia technology, the visual, audio, and animation elements can be packed into one part through the Computer-Based Learning (Fredy \& Soenarto, 2013, p. 164).

The learning process that makes use of multimedia has appeared and developed based on the problems that occur in the technology implementation in the learning process. The use of learning multimedia should also meet several criteria. According to the Joint Committee on Standards for Educational Evaluation (2010), there are five standards for evaluating a 
program. The five standards are namely: (1) Utility Standards; (2) Feasibility Standards; (3) Propriety Standars; (4) Accuracy Standards; and (5) Evaluation Accountability Standards. From the five standars, there are two standars that might be implemented in order to support the evaluation toward the media that has been developed in this study, namely the utility standards and the accuracy standards.

Based on this expanation, the researcher views that she should develop the Mathematics learning multimedia. This multimedia development should be underlied by the perception that learning process will progress well, effectively, and enjoyably if it is supported by the learning media that might draw the students' attention and interest. Multimedia are a combination of multiple elements consisting of text, picture, animation, audio, and video in order to clarify the materials. This learning multimedia then will be packaged into the form of Compact Disc (CD). CD is used because it has quite enormous containing capacity, it has durability, and it has access easiness.

The problem formulations in this study are as follows: (1) how the development of interactive multimedia in the integrative thematic learning process using the feasible Adobe Flash for the Grade IV students in SDN Glagah is; and (2) how the effectiveness of interactive multimedia use in the integrative thematic learning process using the Adobe Flash for the Grade IV students in SDN Glagah is. Then, the objectives of this study are as follows: (1) to generate an interactive multimedia product for the integrative thematic learning process using the feasible Adobe Flash in the Grade IV students in SDn Glagah; and (2) to generate the interactive multimedia product for the integrative thematic learning process using the effective Adobe Flash for the Grade IV students in SDN Glagah.

\section{Method}

This study was a research and development that referred to the Borg \& Gall (1983) model. In this study, the researcher developed a product in the form of interactive multimedia for the integrative thematic learning process in the Grade IV students of elementary school.

The development of interactive multimedia was started by performing a preliminary study on December 2014 in SDN Glagah Yogyakarta.
The data sources consisted of research subjects and research objects. The research subjects were the Grade IV students in the Yogyakarta City, consisting of three grades namely Grade IVA with 32 students, Grade IVB with 31 students, and Grade IVC with 31 students. Then, the research objects were the feasibility and the effectiveness of interactive multimedia using adobe flash for the sub-theme My Food is Health and Nutritious.

\section{Data Gathering Technique and Instrument}

\section{Interview}

In the interview, the researcher performed a preliminary study in order to identify the problems that should be investigated. Deemed necessary, the researcher set up a group discussion involving teachers and colleagues in the form of Focused Group Discussion after performing the activities of needs analysis.

\section{Expert Judgment}

Through the expert judgment, the researcher pursued the validation and the feasibility of the product that had been developed. The product assessment was performed by the material expert and the media expert.

\section{Test}

The test in this research was a set of questions that demanded answers or a set of statements that demanded responses in order to measure the level of individual's capacity. The test was administered in order to identify the effectiveness of the learning media that had been developed. The form of the test itself was pretest and post-test.

\section{Data Analysis Technique}

The data analysis technique that had been conducted included the data analysis toward the model development in order to identify the level of product feasibility prior to the experiment. In the same time, the researcher also conducted the experimental quasi data analysis in order to identify the effectiveness of the product that had been developed.

\section{Results and Discussions}

In general, the research and development process that had been conducted was divided into four parts namely exploration, product development, product testing and revision, and utilization. Each part generated the data that would be the part of research product assembly, 
Jurnal Prima Edukasia, 5 (2), July 2017 - 197

Tri Yuliansyah Bintaro

namely the interactive multimedia for the subtheme My Food is Healthy and Nutritious. Then, each part would be elaborated as follows.

\section{Exploration}

There were two processes in this stage, namely gathering the data and planning the research. After gathering the data and planning the research, the researcher collected the information regarding the learning activities that had implemented the 2013 Curriculum. Next, the researcher reviewed the learning media that had been employed in the learning activities. From this information, the researcher would plan the product development.

The information collecting process was conducted by interviewing and analyzing the needs of the media that the teachers demanded (needs analysis); this was conducted toward the Grade IV teachers in SDN Glagah Yogyakarta. The objective of performing the needs analysis was attaining findings that had been related to the classroom learning implementation. In addition, the researcher would also perform a review toward the theory and the results of the studies that had been relevant to the development plan that had been designed. The activities in this part included reviewing the core competencies, the basic competencies, the indicators, and the materials in the integrative thematic learning within 2013 Curriculum.

Results of Product Development

Based on the data from the preliminary study that had been conducted in order to develop the interactive multimedia, the development of the interactive multimedia was intended specifically for the Grade IV students under the Theme 9 Sub-Theme 1 My Food is Healthy and Nutritious in the second semester. The development was conducted using the Adobe Flash Professional CS3 by referring to the flowchart and the storyboard that had been designed previously and that had been validated by the material expert and the media expert.

Results of Product Testing

\section{Results of Preliminary Field Testing}

The preliminary field testing was conducted for two meetings with 4 students as the subjects. The preliminary field testing was conducted in order to attain the empirical evidence regarding the feasibility of the interactive multimedia in the learning process. In this testing, one person served as an observer because the researcher had difficulties in administering the testing on her own. One of the difficulties was documenting the learning activities.

The implementation of the preliminary field testing involved 4 Grade IV students who had been selected randomly. The field test participants were selected by considering their different capacity. The different capacity lied in the high, the moderate, and the low capacity. The information that had been attained from the field test were the participants' or the students' post-test data.

The analysis toward the post-test data was conducted in order to identify how far the students mastered the competency after attending the learning process using the interactive multimedia. One of the indicators for the competence mastery might be traced through the post-test scores that the students attained; the researcher would consider whether their posttest score had achieved the benchmark or not. In SD Negeri Glagah, the students would be considered passing the benchmark if their posttest score had been at least 66.00. From the same test, the researcher also found that the highest score had been attained by the student whose initial was Ark, namely 90.00, and the lowest score had been attained by the student whose initial was $\mathrm{Mm}$, namely 70.00. The subjects were considered passing the benchmark because they had passed the minimum score namely 66.00. The mean of the learning results in the preliminary field test was equal to 79.17 with standard deviation 8.33.

\section{Results of Field Testing}

The field testing was conducted in SD Negeri Glagah for two meetings and the number of subject for this field testing was 15 students. The subjects were selected randomly by considering their different capacity. The students' capacity was categorized into high, moderate, and low. In this field testing, the researcher selected 5 students with high capacity, 5 students with moderate capacity, and 5 students with low capacity.

The objective of conducting the field testing was implementing the product that had been revised from the preliminary field testing and identifying the effectiveness of the interactive multimedia. In the implementation of 
this field testing, the researcher was assisted by 1 observe. The data that had been attained from the field experiment were the after-learning process test results. In addition, the field testing was also conducted in order to evaluate and to revise the product in the form of interactive multimedia.

The analysis toward the pre-test and the post-test data that had been attained from the field test was conducted in order to identify the effectiveness of the interactive multimedia that had been developed. The results of this analysis were the pre-test and the post-test scores from the 15 subjects. The reason was that the field test made use of one-group pre-test-post-test design. The items that had been distributed referred to the sub-theme My Food is Healthy and Nutritious.

The pre-test was conducted the students made use of the interactive multimedia, while the post-test was conducted after the implementation of the preliminary field test. After the students attended the learning process using the interactive multimedia, they were exposed to the post-test. The data that had been attained from the post-test showed that all of the students had passed the benchmark. The highest post-test score was 97.70, while the lowest posttest score was 73.30 .

Looking at the mean score that had been attained from the pre-test and the post-test scores, the researcher found the gain score that had been equal to 0.43 with moderate category. The gain score was attained from the comparison between the pre-test results and the post-test results. Based on the gain score that had been attained, the researcher concluded that the interactive multimedia that had been developed were effective for operation in the subsequent level, namely in the field implementation.

\section{Implementation Testing}

The implementation testing was conducted in SD Negeri Glagah and the number of subjects was 30 students from Grade IV C as the experimental group and 30 students from Grade IV B as the control group. The implementation testing was conducted for six meetings. The objective of this implementation testing was implementing the product that had been revised from the revision in the previous stage and identifying the effectiveness of the learning process using the interactive multimedia. The data in the implementation testing included the teacher's response questionnaire, the student's response questionnaire, and the student's test result.

The post-test data were the data that had been attained after the students attended the learning process both using the interactive multimedia and the conventional media. The pre-test and the post-test were conducted in order to identify the presence of the absence of certain relationship and also the size of the treatment's influence toward improving the students' learning results.

The implementation testing was conducted in two grades, namely Grade IV B as the control group and Grade IV $\mathrm{C}$ as the experimental group. The number of students in the control group was 29 people, while the number of students in the experimental group was 30 students. The learning process in the control group made use of the conventional media that had been prepared by the teacher, while the learning process in the experimental group made use of the interactive multimedia that had been developed by the researcher. The followings then were the explanation on the learning results of the students in the control group and those in the experimental group that had been attained in the implementation testing.

\section{Control Group}

The pre-test and the post-test data in the control group were gathered from 29 students in Grade IVB of SD Negeri Glagah Yogyakarta. These data were attained from the test that had been administered prior to conducting the learning process and after conducting the learning process. In the control group, the media that had been employed was the conventional media. Within the control group, the researcher found that in the pre-test the highest score had been equal to 86.70 while the lowest score had been equal to 63.30. During the pre-test in the control group there were 2 students who did not pass the benchmark. The mean of the students' learning results in the control group was equal to 74.13 with standard deviation 5.60.

Then, the researcher also found that in the post-test the highest score had been equal to 93.30 while the lowest score had been equal to 70.00. The subjects in the control group were considered passing the benchmark because their scores had passed the minimum requirement namely 66.00. The mean of the students' learning results in the control group for the post- 
test results was equal to 81.84 with the standard deviation 5.87 .

\section{Experimental Group}

The pre-test and the post-test data of the students in the experimental group were gathered from 30 students in Grade IVC of SD Negeri Glagah Yogyakarta. These data were attained from the test that the students had undergone before and after attending the learning process that made use of the interactive multimedia. Then, the sub-them in this study, My Food is Healthy and Nutritious, consisted of 6 learning activities.

The learning activities for the experimental group were conducted in the computer laborary of SD Negeri Glagah Yogyakarta. Then, the researcher found that in the pre-test the highest score had been equal to 83.30 while the lowest score had been equal to 63.30 and that there had been 1 student who did not pass the benchmark. The mean of the pretest scores was equal to 75.99 with the standard deviation 4.66.

In the same time, the researcher also found that in the post-test the highest score had been equal to 93.30 while the lowest score had been equal to 73.30. The students, as a conclusion, were considered passing the benchmark because their scores had surpassed the minimum requirements. The mean of the post-test score was equal to 86.13 with the standard deviation 5.50 .

Learning Result Differences between the Students in the Experimental Group and Those in the Control Group

In order to measure the effectiveness of the interactive multimedia in the implementation testing, the researcher might view the students' benchmark achievement and the different media that had been employed in both groups. Then, in order to identify the presence or the absence of benchmark achievement between the control group and the experimental group the researcher employed the independent sample t-test. In this $\mathrm{t}$-test, the researcher calculated the independent sample t-test using SPSS 16.0. Prior to the testing, the researcher performed the analysis prerequisite test namely the normality test and the homogeneity test. The followings were the analysis toward the normality test and the homogeneity test.
The researcher performed the normality test by using the SPSS (Statistical Product and Service Solution) 16.0. The normality testing was based on the following hypothesis.

$\mathrm{H}_{0}$ : The sample comes from the normally distributed data.

$\mathrm{H}_{1}$ : The sample does not come from the normally distributed data.

$\mathrm{H}_{0}$ would be rejected if the significance value had been smaller than $(\alpha=0.05)$. On the other hand, if the significance value had been greater then the normality and the homogeneity would be met. The followings were the results of the students' pre-test and post-test scores.

Table 1. Results of Normality Test

\begin{tabular}{cccc}
\hline Test & N & $\begin{array}{c}\text { Kolmogrov- } \\
\text { Smirnov Value }\end{array}$ & $\begin{array}{c}\text { Significance } \\
\text { Value }\end{array}$ \\
\hline Pretest & 59 & 0.684 & 0.737 \\
Posttest & 59 & 0.894 & 0.401 \\
\hline
\end{tabular}

Based on the data that had been displayed in Table 1, the results data normality test showed that the normality testing value with the significance 0.737 had been greater than the probability 0.05 . Therefore, H0 was accepted and the data were normally distributed.

\section{Homogeneity Test}

In addition to performing the data normality test as a prerequisite, the researcher also conducted the homogeneity test. The homogeneity test was intended to identify whether the sample that had been manipulated was homogenous or not. In order to identify whether the variance of the population was homogenous or not, the researcher formulated the following hypothesis:

$\mathrm{H}_{0}$ : The variance of population for the learning results between the respondents in the control group and those in the experimental group is homogenous.

$\mathrm{H}_{1}$ : The variance of population for the learning results between the respondents in the control group and those in the experimental group is heterogeneous.

If the probability had been greater than 0.05 (> 0.05), then $\mathrm{H}_{0}$ would be accepted and the variance would be homogenous. On the contrary, if the probability had been lower than or equal to $0.05(\leq 0.05)$, then $\mathrm{H}_{0}$ would be rejected and the variance would be heterogenous.

Table 2. Results of Homogeneity Test 
Jurnal Prima Edukasia, 5 (2), July 2017 - 200

Tri Yuliansyah Bintaro

\begin{tabular}{cccc}
\hline Test & N & F Value & Significance Value \\
\hline Pretest & 59 & 0.848 & 0.361 \\
Posttest & 59 & 0.289 & 0.593 \\
\hline
\end{tabular}

Based on the results in Table 2, the researcher found that the homogeneity test with the significance 0.361 had been greater than the probability 0.050 . Therefore, H0 was accepted and the data were homogenous.

The Difference on the Effectiveness of

Interactive Multimedia between the

Experimental Group and the Control Group

Because the data were normally distributed and were homogenous, the researcher employed an independent sample ttest. The calculation of the independent sample t-test was done by operating the SPSS 16.0 program. The interactive multimedia product that had been developed would be considered effective if the post-test results in the experimental group had been better than that in the control group. The followings were the hypotheses that the researcher would like to test:

$\mathrm{H}_{0}$ : There have not been significant differences between the post-test results of the experimental group and those of the control group.

$\mathrm{H}_{1}$ : There have not been significant differences between the post-test results of the experimental group and those of the control group.

Table 3. Differences on the Post-Test Results between the Experimental Group and the Control Group

\begin{tabular}{|c|c|c|c|c|}
\hline Information & $\mathbf{N}$ & Mean & $\begin{array}{l}\text { Std. } \\
\text { Dev }\end{array}$ & $\begin{array}{c}\text { Std. } \\
\text { Error } \\
\text { Mean }\end{array}$ \\
\hline $\begin{array}{l}\text { Control } \\
\text { Group }\end{array}$ & 29 & 81.8414 & 5.87881 & 1.09167 \\
\hline $\begin{array}{l}\text { Experimental } \\
\text { Group }\end{array}$ & 30 & 86.1300 & 5.52862 & 1.00938 \\
\hline
\end{tabular}

Based on the results in Table 3, it was apparent that the mean of the post-test results for the control group had been equal to 81.84 while the mean of the post-test results for the experimental group had been equal to 86.13. From these mean scores, the researcher would like to conclude that the post-test results between the control group and the experimental group had been different.

In the homogeneity test, the researcher found that the variance had been homogenous. Therefore, the analysis toward the independent sample t-test should make use of the equal variance assumed. From the SPSS output, it was apparent that the $t$ value in the equal variance assumed had been -2.888 with df 57 and significance 0.005 (two tail). The t table value that had been attained was equal to 2.000 . Because $t_{\text {count }}>t_{\text {table }}$, namely $-2.888>2.000$, and the significance value $<0.05$, $\mathrm{H} 0$ was rejected and $\mathrm{H} 1$ was accepted. In other words, the posttest results of the experimental group had been better than those of the control group with the rate of significance 0.05 . Based on these results, the researcher concluded that there had been significant differences on the post-test results between the experimental group and the control group.

The preliminary capacity of the students in both groups was relatively equal. The mean of the pre-test scores in the experimental group had been higher than that of the control group. However, in a closer look, the pre-test scores of the experimental group that had been higher was caused by the fact that several students had earned quite high value.

In terms of post-test scores, the experimental group had higher mean score than the control group. The reason was that the experimental group had quite significant improvement on their mean score in comparison to that of the control group. In other words, the use of interactive multimedia had provided positive impacts toward the students' learning results.

In terms of both pre-test scores and posttest scores, the mean of learning results had improved. Within the experimental group, the overall learning process made use of scientific approach-based interactive multimedia. The students were actively involved in the learning process. Such active involvement had been in accordance to the characteristics of integrative thematic learning process; this learning process had been supported by the scientific process and, as a result, the students became more capable in applying their knowledge. Through the interactive multimedia, the researcher also presented the exercises that had been related to the concepts that the students were studying. The exercises that had been presented were various and there are also the exercises that took the form of games; such exercises would reinforce the students' understanding toward the materials that they learned. With the exercises that had been available in the interactive multimedia, the students might train themselves 
Jurnal Prima Edukasia, 5 (2), July 2017 - 201

Tri Yuliansyah Bintaro

to complete the comprehensive test items. Therefore it was not surprising that the mean scores of the experimental group had been better than those of the control group. The learning process that had been applied in the control group still centered on the teacher. In addition, the media that had been applied were the figures that had been available from the student book. The students had not taken active participation in the learning process. Therefore, it might be concluded that the learning results of the students in the experimental group had been better than those of the students in the control group. The researcher might also argue that the learning process in the experimental group that made use of the interactive multimedia had been more effective.

\section{Final Product Review}

The final product of interactive multimedia had been the results of preliminary draft revision, limited testing revision, and field testing revision. The final product was the interactive multimedia for the sub-theme My Food is Healthy and Nutritious. The interactive multimedia that had been developed aimed to assist the teachers in delivering the learning materials and also to encourage and to motivate the students in attending the learning process. The students were assisted in recognizing multiple types of healthy and nutritious food that they encountered in the daily life. The learning materials in each learning activity were presented differently and were adjusted to the learning materials and the learning objectives.

The Adobe Flash interactive multimedia that had been resulted in this study had very good quality in the form of interactive learning $\mathrm{CD}$. Then, the product specifications were as follows: (1) type of the file is application (.exe); (2) the biggest size is $102 \mathrm{MB}(107,384,832$ bytes); (3) the display card made use of $1024 \mathrm{x}$ 768 pixel; and (4) the frame rate (the frame speed from 25 frames per second) was 25 fps.

In addition, the basic types that had been stored in the Adobe Flash interactive multimedia were namely: (1) the texts that had been used were Times New Roman, Arial, and Comic San MS with adjusted measures; (2) the image format that had been used were PNG and JPEG; (3) the audio format in the Adobe Flash interactive multimedia was MP3; (4) the video format that had been used was Flash Video (.flv); and (5) several animations had also been used in order to add the beauty of the Adobe Flash interactive multimedia.

The interactive multimedia that had been resulted in this research and development study had several advantages, namely that it was an interactive multimedia that contained the scientific approach-based integrative thematic learning process, it had attraction, it had interactivity, and it also had user-friendliness. The interactive relationship between the students and the multimedia was built by the games that involved matches, drag and drop, and puzzle. Daryanto $(2010$, p. 53) mentioned that one of the characteristics that interactive multimedia had was interactive, in a sense that multimedia had the capacity to respond to the users. This statement was confirmed almost by all of the students, since they could easily operate the interactive multimedia, and such confirmation implied that the students had really understood the commands within the multimedia.

The material presentation in the interactive multimedia also made use of scientific approach steps. The scientific approach consisted of five stages, namely observing, raising questions, experimenting, reasoning, and communicating. The activities of observing prioritized the meaningfulness of the learning process. The activities of raising questions might implied that teachers raised questions to their students in order to guide them; when the teachers answered the students' questions, they encouraged the students to become good listener and learner. The activities of experimenting were the activities that the students performed within an experiment. The activities of reasoning were associating multiple ideas and events into memory. Last but not the least, the activities of communicating were the collaborative activities that aimed to solve the problems for the sake of the common needs by sharing ideas and providing suggestions from one to another.

\section{Conclusions}

Based on the results of the research and development study, the researchers would like to draw several conclusions. First, the interactive multimedia that has been resulted are feasible for implementation in the Grade IV students from SD Negeri Glagah Yogyakarta, according to the interactive multimedia expert, this product has earned the A predicate and has belonged to the "Very Good" category. Then, according to the media expert, this product has also earned the A predicate and has belonged to the "Very 
Good" category. Second, the interactive multimedia that have been resulted are also effective for implementation in the Grade IV students of SD Negeri Glagah Yogyakarta for the learning process under the sub-theme My Food is Healthy and Nutritious. In terms of percentage on the students' learning result achievement, generally the students have already improved themselves and this improvement can be found in their pre-test and post-test scores. The differential test results between the control group and the experimental group show that there has been significant difference between the learning results of the control group and those of the experimental group.

The development of the interactive multimedia for the Grade IV students in the elementary schools have been proven in terms of feasibility and effectiveness; as a result, the researcher would like to suggest the Grade IV teachers to use this interactive multimedia within the learning process for the sub-theme My Food is Healthy and Nutritious. Then, similar interactive multimedia may be developed further for different learning materials.

\section{References}

Borg, W. R., \& Gall, M. D. (1983). Educational research: An introduction. New York: Longman.

Daryanto, D. (2010). Media pembelajaran peranannya sangat penting dalam mencapai tujuan pembelajaran. Yogyakarta: Gava Media.

Djamarah, S. B., \& Zain, A. (2010). Strategi belajar mengajar. Jakarta: Rineka Cipta.
Fanny, A. M., \& Suardiman, S. P. (2013). Pengembangan multimedia interaktif untuk mata pelajaran ilmu pengetahuan sosial (IPS) sekolah dasar kelas V. Jurnal Prima Edukasia, l(1), 1. https://doi.org/10.21831/jpe.v1i1.2311

Fredy, F., \& Soenarto, S. (2013). Pengembangan multimedia pembelajaran matematika pada materi bilangan bulat kelas 4 SDN Lempuyangan 1 Yogyakarta. Jurnal Prima Edukasia, 1(2), 162-172. https://doi.org/10.21831/JPE.V1I2.2633

Joint Committee on Standards for Educational Evaluation. (2010). The program evaluation standards: A guide for evaluators and evaluaOtion users $\left(3^{\text {rd }} e d\right)$. California: Sage

Kemendikbud. (2013). Kurikulum 2013Kompetensi dasar untuk sekolah dasar $(S D) /$ madrasah ibtidaiyah (MI). Jakarta: Kementerian Pendidikan dan Kebudayaan

Kemendikbud. (2013). Peraturan Menteri Pendidikan dan Kebudayaan Nomor 67, Tahun 2013, tentang Kerangka Dasar dan Struktur Kurikulum Sekolah Dasar/Madrasah Ibtidaiyah.

Munir, M. (2012). Multimedia: Konsep \&amp; aplikasi dalam pendidikan. Bandung: Alfabeta.

Warsita, B. (2008). Teknologi pembelajaran landasan dan aplikasinya. Jakarta: Rineka Cipta.

Sidhu, S.M. (2008) Interactive Multimedia. Information science references. 2, 455462. 